を重ねてみて，現在われわれの得ている所見の信頼性を ためすとともに, 物理的, 感光理論的にも再検討を加光, しっかりしたオートラジオグラフィの論拠と処理法を確 立して, 今後の研究の発展に資したい.

\section{2. 電顕的オートラジオグラフィの今後の動向}

現在をでるかなりよい実験結果を示している研究所見 の報告もあるが，どららかといえば技術の開発に力が注 がれてきている．最近ではほとんぞ技術的に安定してき たのでこれから電顕オートラジオグラフィの真価が発揮 されると思われる．単にラベルされた種々の物質を用い てそのとりこみを見るだけでなく，標識化合物を用いて， まず生体内または試験管内でラベルされたある物質を生 合成し，これを用いて正確な電顕的オートラジオグラフ 亿の実験を行ならことも試みられてきている。たと艺ば Neustein (1966) は， ${ }^{3} \mathrm{H}$-DL-leucine を用い，鬼の網状 赤血球をとり出して試験管内で ${ }^{3} \mathrm{H}$-hemoglobin を生合 珹させ，このトリチウムでラベルされたへモグロビンを トレーサーとして鬼の耳静脈内に注射し, 腎蔵の尿細管 上皮からのへモグロビンの吸収過程を見ている，これと 洞じょうな方法は，現在よく行なわれている ferritin 抗体法の代わりに, トリチウム標識の抗体を用いて, 抗 元抗体反応をオートラジオグラフィ下に調べることも可 能であろう。また，われわれの開発してきた超微粒子現 像法はこのような高分解能オートラジオグラフィにはう ってつけといえる.現在われわれの研究室と三共中央研 究所の共同研究で, vitamin $B_{1}$ 誘導体を標識し, この 吸収機構や，さらに作用機構を明らかにしょうとしてい るが，この物質ははなはだ水溶性であるために，われわ れはすず不溶性の物質にすることに成功し，この方法を 利用して目下種々の基礎実験を試みつつある. 研究が進 展するほどにオートラジオグラフィのみでは説明しきれ なくなってくることは明らかなことで, 他の電顕および 光顕レベルでの組織化学的方法や, 生化学的ならびに生 理学的実験結果を充分に考慮する必要がある。
使用アイソトープの細胞内固定が充分であるかどうか を一方では充分注意して，結果の判断をあやまらないよ らにしなければならない。したがって, 使用アイントー プの総量, activityをよく記録して扣き, 固定, 脱水, 包埋のそれぞれのステップでどの程度失われ，最後にぞ の程度の activity が残留しているかを比較検討するこ とが望ましい，われわれもあらためて発表するが， ${ }^{3} \mathrm{H}-$ vitamin $B_{1}$ 誘導体について各ステップで記録をとって みて，われわれの開発した組織内固定法がきわめてすぐ れた結果を示すことを示している。しかしをた，一方で は, activity の計測の結果のみから実験結果を判断して しまらことも危険であることを，よく銘記すべきである。 最後に，放射性同位元素の扱いには充分な注意を行な い，実験者自身を護ると同時に，他人に迷惑をかけない ように心がけねばならない，使用にあたっては法に定め られた場所で，適正な条件下で行ならことを，拈互いに くれぐれも注意したい。

\section{文献}

外国文献の大部分のものは次の総説をご覧願いたい; 水平敏知：電子顕微鏡的 Autoradiography一とくに国産 原子核研究用生乳凨と微粒子現像を中心として一 Radioisotopes, 14, 240 254 (1965).

その他；

水平敏知, 黒滝光明 : 国産原子核乾板用生乳剂による電子顕 微鏡的 autoradiography，医学のあゆみ，49 (14), 725 $\sim 733$ (1964).

水平敏知: 国産原子核乾板用生乳剤による電顕的 autoradiography 手技, J.Elect. Micr., 13, No. 2, 75 79(1964). 水平敏知他: The Twelfth Symposium of the Society of Electron Microscopy, Japan Held at Nagoya Municipal Science Museum, October 21 and 22, 1965, Session III, Autoradiography; J.Elect.Micr., 14, No. 4, 318 336 (1965).

V. Mizuhira, K. Uchida and H. Ozawa : The E/M-Autoradiographic Studies of the Estradiol-17 $\beta-6,7-{ }^{3} \mathrm{H}$ in the Mice Uteri, Sixth Int. Nat. Cong. Elect. Micr., Kyoto, p. 85, 1966 (Maruzen).

H.B. Neustien and A.B. Maunsbach : Hemoglobin Absorption by Proximal Tubule Cells of the Rabbit Kidney. A Study by Electron Microscopic Autoradiography, J. Ultrastructure Res., 16, 141 157(1966).

\title{
VII. “むすび”にえて
}

——な゙これほどの分解能が得られるか—

水平 みなさんの努力でわかりやすい解説ができて， 私どもとしても嬉しいし，読まれる方たちもずいぶん参
考になるのではないかと思います．私の場合，電顕レべ ルのオートラジオグラフィの使用者といら立場にありま 
すと，感光理論など物理的な問題がわからないところだ らけですが，その点，この講座で，小西さん，平田さん 飞わかりやすく解説していただいたことは，有益であっ たと思いますけれども，ただ誌面が少ないので意を尽せ なかった面もあるのではないかと思います。そういらこ とも含めて，われわ使用者，すなわち素人の立場から， わからない点をできるだけ話し合ってみたいと思らわけ です。ひとつよろしく㹉願いいたします。

さて, 私どもで約 1 年半ぐらい前から, 電顕的オート ラジオグラフィについて，根本的に考光直さなければい けない段階にきたものですから，私たちだけではどうし ようもなくて，物理の面で小西さん，感光理論の面で平 田さんに，月に 1 度とかいら間隔で寄り合っていただい て、データを持ち寄って，わからないところを互いに 理解し合うといらことをしてまいりました。最初は，た とえば私が怙話することは，小西さんと平田さんには， なかなかわかっていただけないし，逆に小西さん，平田 さんの専門的な説明は，われわ机にはぴんとこないとい ら状態でしたけれぞも，それが回を重㸚るごとに，打互 いによくわかるようになってきて，今まで物理的に説明 されていたことが，実際にはそれだけでけ説明できない ことがたくさん出てきました。.今までの解釈が案外，役 立たなかったり，あまり主役でないと思われていたよう な理論的な説明が，かえってわれわれの実際のデータの 説明に役立つのではないかといら問題も出てきました。 お互いに話しているらちに，かなり理論的な裏づけのあ る道筋がわかってきつつあるというのが現在の状況では ないかと思いますね。

小西水平先生から初めご相談を受けたのは，分解 能といら点で， $\beta$ 線の飛程の長さからいいますと, 電子 顕微鏡の視野外飞出てしまうのではないかという疑問か ら，実際はどうなのだろらかといらことで，ご相談を受 けたわけです。たしかに，実験事実は分解能が比較的よ いのですが，飛程の問題から考えたら，一見分解能がよ いとは考兄られない，そこで，問題を解決するためには， $\beta$ 線の性質を理解しなければならない，それには， $\beta$ 崩 壊と $\beta$ 線のエネルギースペクトルを知る必要があるとい うことになります．次に， $\beta$ 線が物質を通過するときに は土ネルギーを落とすといらことですね，その落とした エネルギーが “感光させる” 源, 結局は, オートラジオ グラフィの源になっていると考兄られる.

さらに，ディテクターである乳剂との関係が問題にな るわけですけれども，非常に細かい分解能が得られると いらことは，どうしても $\beta$ 線源と八ロゲン化銀の結晶と
の幾何学的な条件や，線源から出た $\beta$ 線がハロゲン化銀 の結晶にェネルギーをどらいうらうに落とすかといらを ころを細かく考えてゆかないと出てこない，電顕用の切 片のうすさ $(500 \AA ̊ \AA)$ で, 乳剤も単層であるということ から考光ますと, 実際に出てくる放射線は四方化出宗す から，そこには幾何学的な要素が分解能に対する1つの 大きな要素となっていると考学られます。したがって， 飛程の問題はバックグラウンドに関与してきますが，分 解能には直接関係がないと思います。

水平 今の打話に関連して，実際に電子顕微鏡レべ ルのオートラジオグラムを作ってみると，目的物に現像 銀が非常にきれいにのってくるといら事実がたくさん出 てきた．細胞学者としてはそれだけの事実で喜んでしま らのですけれども，ある放射線物理を勉強している人に， そらいう写真を見せむしても，「そんなことはとてもあ り得ない」といら批判をたびたび受けたわけです。

たとえばトリチウム ${ }^{3} \mathrm{H}$ を使った場合，その平均飛程 は $15,000 \AA(1.5 \mu)$ で, 電子顕微鏡で見方る像の上に， たとえば像を中心にして $15,000 \AA ̊$ もバラッキがあって は, とても分解能の上でよいとはいえませんし, 場合に よっては, 電子顕微鏡のレベルでは使えないということ になります。ところが，実際には像の上によい局在を示 すと考穴られることから, 今のよらな問題になったわけ です。

さらに，また別の問題がありまして，普通の現像法で 処理したのでは, 現像銀が大きくなって, 電子顕微鏡で 見ると，1つの現像銀それ自身が，だいたい $0.3 \mu$ にな ってしまう，そのことだけで，とんでもないェラーがで きて，どこに $\beta$ 線の線源が含まれているかを見るのに， 電子顕微鏡を使う意味がなくなるわけです，それで，で きるだけ現像銀を小さくしなけ机ばならないという問題 が出てきました。われわれも微粒子現像の方法を検討し て，小さな現像銀を作ってみたところ，数百周のオーダ 一で構造物の上にのって出てくる。これはいったい理諭 的にどういらことかといらことですね.

ところで，光顕のレベルでも微粒子現像をやりますか. 中村やりません，われわれのレベルでは，その細 胞にある線源から出たといら確証があればよい。つまり， 隣の細胞からきていなけ机ばよいわけです，乳剤の厚さ を薄くして，飛程の短いものを使ってやる．もし長いも のしか使光ないならばやめてしまう。せいぜい隣り合っ た細胞の分解能さ光あればよい，多少のエラーは勘茾し ていただくわけです。それは全身オートラジオグラフィ にしても，飛程の長いものを使光ば，臓器同士は隣り合 
っているから，それは隣の蔵器からのものかもしれない. 飛程の長いのを使うと, 水平先生の㧍っしゃるような意 味での分解能は保証できないと思います，つまり，分解 能については, 平田さんにご相談しなくても，われわれ の範囲で解決できることなのです.

小西 マクロのレベルでは, 分解能の問題というょ りも，見かけ上の“ぼけ”の問題がありますね.

ところで, 電子顕微鏡レベルの場合は, 乳剂粒子 $1 つ$ 1つがディテクターとして意味をもっていますから， $\beta$ 線が乳剤粒子に入ってくるのは, 確率現象として考兄 られる.ソースとディテクターの距離を考学る場合, 分 解能がよいといらことは, 距離の近いところに現わ机る チャンスが多く，遠くにあるときには少ないということ です。といらのは, 裏を返せば， $\beta$ 線に飛跡があるかぎ り， $\beta$ emitter から出て, これが遠くのところで, 現像 銀を作っても扔かしくはない, ところが, その結果は電

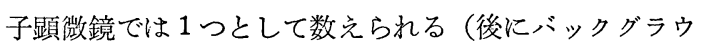
ンドで処理してしまうけれぞも)。電子顕微鏡をのぞい て意味があるというのは, emitter と黒化銀粒子との対 応が確率高くあるといらことで, その確率といらことを 忘れてはならないと思います。

水平 光顕, あるいはマクロのオートラジオグラフ 亿の場合には, 切片が電子顕微鏡に比べると析違いに厚 いから, 切片の厚みの中での線源の位置がかなり大きな 問題になりますね.いろいろバリエーションに富んでい るのが, 結果に执いて有効に効いてくるといらことで, したがって, 乳剤の層が厚いといらことが重要な問題に なりますね，そのため，使う放射線の種類，アイソトー プの種類が非常に制限を受けるといらことになるわけで すね. その場合には, 特殊な現像処理, いわゆる微粒子 睍像はあまり意味がないといらことですか.

中村 そこまで追いかけても意味がないほどラフな 仕事をしているといらことだと思います。それで充分マ ク口の目的を達しているといらことですね.

中島 原理的にはどんなェネルギーの高いものでも 使いらることになるということですね.

水平 マクロオートラジオグラムの場 合は, ${ }^{3} \mathrm{H}$ は汪 とんぞ無効だといらことを書いていますけれども，それ はどういう意味ですか.

中島 マクロオートラジオグラフィの場合, 現在で は, X線のフィルムを使って感光させて牱りますが, 乳 剤膜の上にゼラチンの厚い保護膜があるために ${ }^{3} \mathrm{H} の \beta$ 線が届かない，そのために使っても無効だという現状で す.
水平 それは解決できる見通しが立って打りますか。

平田乳剤をフィルムベースにじかに塗ればよいと いらことですね.

水平 一種のディピングの方法で処理すれば, 可能 だといらことですか.

進藤固定, 包埋といら過程がぜんぜんないから， ミクロと同じように乳剤を切片に直接塗ることは不可能 ですね. 原子核用の乳剤をベースの上に塗り，それにコ ンタクトすれば，きれいなオートラジオグラムが得られ ます。

水平 コンタクト法によって, 厚い吸収層をなくす ような方法をとればよいわけですね.

進藤 マク口の場合でも, 解像力の点からは飛程が 短いものほどよいわけです.

水平 それは理論的に考光れば, マクロの場合でも ${ }^{3} \mathrm{H}$ がいらばんよいですね.

中島 にじみが少ないから非常にきれいな写真が得 られて,かなり微細な部位への ${ }^{3} \mathrm{H}$ の局在が判別できま す.

水平 これからの発展が大いに期待されるといらこ とですね. ところで, 感光理論のほうに入ってゆきたい と思いますが……

平田私が書いたことは, 八ロゲン化銀の結晶 1 ○ 1つがディテクターとして働くといらことなのです. 事 実, マクロなりミクロのオートラジオグラフィの分解能 を論ずる範囲内では，それで充分だったわけですけれど も, 電顕レベルでの分解能を論ずる場合には, 実際に $\beta$ 線が入った点と, 潜像ができる点との相互関係が問題に なってくるだろらと思います。

今までの感光理論では, 八ロゲン化銀の結晶内に利い て, 入射位置 A と実際に現像核のでさるとされている位 置Bは, ぜんぜん関係がなくて, 潜像のできる位置は, このハロゲン化銀結晶それ自体の性質に依存していると する考方がなされてきました，事実，光を照射した場 合には, 光量子が吸収された地点と, 実際に潜像ができ

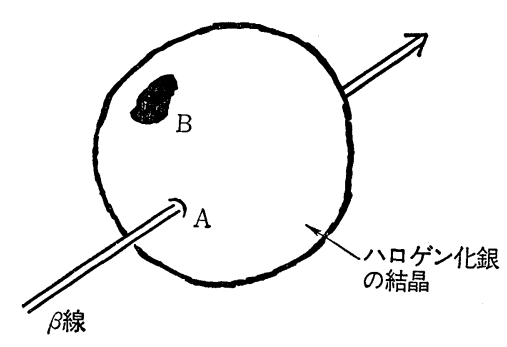


る位置とは関係がありません，しかし $\beta$ 線のように非常 に短い時間に，局部的に多量の電子を作りだすような場 合には，実際にそれが入った地点と，潜像のできる位置 が必ずしも無関係だとはいいきれません，それを実証す る方法は, 現在のところないのですが，さき汪どの水平 先生の実験結果からみますと, そらいうこともあるので はなかららかと考光させられます，このことは感光理論 そのものに関係のあることですから，早急に結論できる 問題ではないのですけれども，非常に興味のあることで， 逆にいえば，現在のような実験を重ねることによって， こらいら問題がもっとはっきりわかってくるのではない かと考えて㧤ります.

水平感光理論では, 感光核を設定しているわけで すね.それは浮んとうにあるのでしょうか，位置は決ま っているものでしょらか.

平田それについて, 結晶中のどういう場所に感光 核があるかといらことは，まだはっきりとはわかってい ません，というのは，照射したものが $\beta$ 線か光かによっ て，潜像のでき方が違うのです．同じハロゲン化銀であ っても, 場合によって潜像の位置, 分布が異なってくる といらのは, 潜像の元である感光核が, かなり広、範囲 に存在することを示しているといえます。したがって， 結晶との対応が難しいところですが，一応はハロゲン化 銀の表面の構造上の特異点にそらいらものができるだろ らといら考方が今までとられてきました。

水平 そうしますと, 結局, 1 つのハロゲン化銀グ

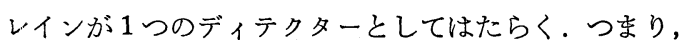
潜像の位置は, ミニマムのグレインサイズによって規定 されるといらことですね. 電顕の場合, 光の波長の $1 / 10$ ぐらいの薄さで，その上にただ 1 列に臭化銀が並んでい

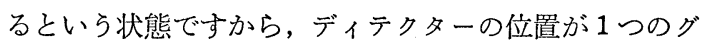
レインサイズによって決まってくるということは，だれ も異存がない. しかし, 実際の写真では, 1 つのグレイ ンサイズよりは，はるかに分解能のよい，きれいなもの が得られているのですから，これをどら解釈するかとい らことが，われわれの悩みなのです。

平田 非常にインテンシィティの強い短時間の露光 を与えた場合とか， $\beta$ 線のような荷電粒子によって潜像 ができる場合には，八ロゲン化銀結晶の表面や内部に， 分散した潜像がたくさんできるといらことがいわれてい ますし，現実に金液による物理現像を行ならと，解説の 中で水平先生が示しているょうに(写真 6,7), 電子顕微 鏡でも分散した潜像を見ることができます．したがって， そういら分散されるような状態で感光した八ロゲン化銀
では，潜像は全面に分布しますから，ハロゲン化銀中の 特異点が特異性を失ってきます。そこで， $\beta$ 線が吸収さ れてェレクトロンがたくさん発生した領域のほうが, 結 晶の他の部分より潜像が確率的にできやすいと考兄ても， ある意味では納得性が出てきます。とくにェネルギーの 極端に低い $\beta$ 線の場合には, 、ロゲン化銀粒子内の 1 カ 所で汪とんぞ吸収されるわけですから，その部分に局部 的にフリー・エレクトロンがたくさん発生するというこ とがありえます。

水平ところで, 微粒子現像について, もら1つ私 ぞもが当面している問題があるのですが. 解説の中にも 記述されて抢りますけれども，たとえば ${ }^{3} \mathrm{H}$ で感光させ た場合と同じ条件で，それよりも10 倍ぐらいェネルギ 一の強い ${ }^{35} \mathrm{~S}$ とか, ${ }^{45} \mathrm{Ca}$ とかで感光させたものを, 同 じ現像方法で微粒子現像をすると, ${ }^{3} \mathrm{H}$ の場合は黒い 1 つの点として現像銀が出てくる.ところが, エネルギー の強いものでは, ${ }^{3} \mathrm{H}$ よりも小さめの, やはり点として 出てくるけれども, それが本当の点ではなくて, 電子顕 微鏡の写真をとると，小さな点が数個集まって，あたか も 1 個の点に見えるということです（写真 9,10）.

この問題を考光てみると, エネルギーが強くて, 臭化 銀に対するェネルギーのロスが少ないから，拈そらく大 部分は通過してしまって, 普通の現像方法では現像され ないような小さい潜像ができるのではないか.もちろん， これを金で鍍金して，エロンの現像をやってみるわけで すが，小さな粒が集まっているような状態に見劣るとい うことは， $\beta$ 線が飛び込んだとき，ある一定の体積の中 にできる銀の原子の集団が， ${ }^{3} \mathrm{H}$ の場合と比べて，まば らで, 少ないのではないでしょらか.

物理的な根拠もない危険な話ですけれども， ${ }^{3} \mathrm{H}$ の場 合も同じょうに解积することができるならば，われわれ がやっている現像処理で想像以上の局在を示すといらこ との1つの説明の助けになるのではないかということを 考えてみたりしたけれども，どうでしょらか。

小西 そのことについて，私はこういうらう的克 たわけです. 水平先生のいわれている微粒子現像を, こ こでは普通の現像のように潜像を大きくしないで, ほと んど潜像のますでとどめる意味の微粒子現像である, と いらことを前提にして考觉ますと，エネルギーの高い $\beta$ 線のほうが，ストッピング・パワーが少ないから，局部 に落ちるェネルギーは小さい，そこで潜像ができうる最 低の数の銀が固まって, 安定化できる。しかし，これは 最低の話であって，実際はふつらそれを上回っている. そうすると, 同じ $\beta$ 線にヒットされても，その所でフリ 
一・エレクトロンがたくさんできて、潜像に銀原子がた くさんできるか，あるいは少なくできるかによって，っ まり，できあがった安定化銀の固まりである潜像が大き くできるか小さくできるかによって, 観察された像は違 らといらことを考劣てみれば，やはりェネルギーのたく さん落らる低エネルギーの $\beta$ 線のほらが潜像は大きい， エネルギーが高い $\beta$ 線では小さい潜像ができることも， そのへんでは納得できるように思らのですが．

もら1つは，ふつら使われている $700 \AA ̊$ の八ロゲン 化銀では， $\beta$ 線は汪とんど通過すると考兄てよいと思い ます。シネティックスの中にあるように，自分がそのも のになった気で考光る，たと党ば，原子レベルまで自分 自身を小さくしていったと考えますと，ハロゲン化銀結

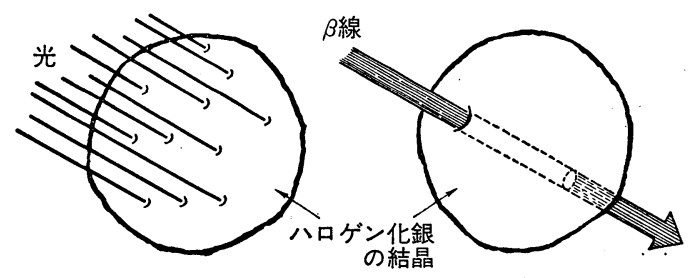

晶の大きなものを想像して, 普通の光による感光は, 光 が結晶全体にぱらぱらと雨粒のように当たる， $\beta$ 線の場 合は結晶の真中をホースでねらったように， $\beta$ 線が通過 した道筋に沿って，比較的たくさんのフリー・エレクト ロンを作る. 再結合のチャンスなどを考えると, 結局, 通った道筋の近辺しか潜像ができないと考兄られる. 光 の場合は全体に当たりますから, 当然, 全体に潜像がで きあがる。

さらに，現像するといらことを考党てみすすと，現像 液は外部からハロゲン化銀に作用するわけですから, 結 晶の中に潜像ができたとしても，それは現像されない。 現像されるのは八ロゲン化銀の表面にある潜像であると 考えられます．このことと， $\beta$ 線が通過した部分だけに とくに現像核がたくさんできるという前提に立てば，こ れは危険な推論かもしれないが，1つのハロゲン化銀の 結晶で $\beta$ 線がヒットした部分の表面に潜像が観察されて よいのではないか, と考光たわけです。

平田＼cjkstart再結合しやすいということをフリー・エレク トロンのライフタイムが短くなったというららに考光れ ば, 線源から最も至近距離に潜像ができても不思議では ないだろうということですね.

水平 もう 1 つ説明が非常に困る問題があるわけで して，臭化銀の粒子に $\beta$ 線が真下から出てヒットする場 合に，今までの括から，A点が現像されて残ってもよ

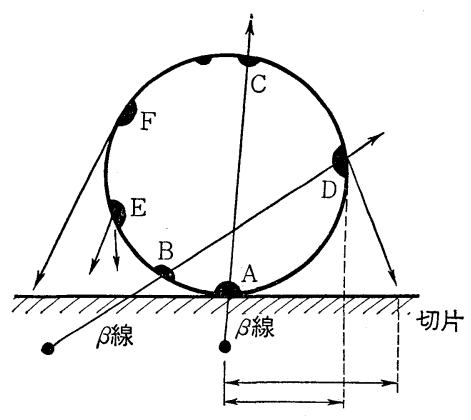

$\beta$ 線により臭化銀粒子内にでさる潜像と，それら が微粒子現像後, 切片上に残る位置的可能性.

いといらことは, ある程度, 理解できる，ところが，真 下ではなく，横のほらから $\beta$ 線が飛んでさたものがあれ ば，Bにも潜像ができるわけですから，そういうものが 現像して残った場合には, 最終的には 1 つの臭化銀粒子 の径よりも大きなバラッキとして像が出てこなければな らない，ところが実際にはそのようなバラッキが見られ ない，いちばん安易な考方方としては，理論的な根拠は ないけれども， $\beta$ 線が入ったところは臭化銀粒子の表面 にイオン化が起こっている. しかし，横から入って，臭 化銀の表面に近いところにできた潜像（B，E）は，現像 核として現像されても，アルカリの鉛染色処理の間に洗 い流されて，切片の上に残らないで，とれてしまう．最 後まで残る可能性としては， $\beta$ 線の侵入部にいちばん強 く臭化銀のイオン化が起こり，切片と接している点から 入ったところでは，臭化銀の表面に出た銀イオンの集団 が，微粒子現像後，切片にこびりついて残っているとい らふらに考光られないか。皁うすれば， B, C, D, E, F などというものはネグルことができるといらことなので すけれどる…

小西 そこですがね. 切片と接触していない部分は 流してしまうといらことになりますと, 最終的には八口 ゲン化銀の結晶が切片之接している底面だけが有効な働 きをするということになるわけですね，底面に及線の七 ットによって潜像ができれば，それが底面に残りらると いうことになって，結果的に底面だけがディテクターと いらことになるわけで，そうすると，極端に薄いディテ クターを考皃ることと同じことになる.

そこで， $\beta$ 線源とディテクターの幾何学的な条件を考 えると, 結局, ディテクターの真下から $\beta$ 線が出たとい う確率は高くなって, その意味では, 実験事実に合う分 解能のレベルまでを，ある程度説明できる、けれども， 問題は実際にサンプル内にある線源がどれだけハロゲン 化銀をとットしたか. ゼラチン除去と染色処理をしたら， 
ぞれだけの潜像が流れたか、それがある程度，なんらか の形でわからないとだめだと思います．たとえばヒット されて結晶の上に潜像がでさているはずなのに, 現像し， 染色すると，それが流れてしまう．染色をした場合と， しない場合とで，銀粒子の数がどのくらい違うか。かな り違わなければ，そのことはいえないといらことで，な かなか難しい問題だと思いますね。

水平 らつらは, 現像処理をてい水いにやって,ア ルカリ染色でゼラチンを除いて電子顕微鏡で見るのです が, それをやらないで, 現像処理をしただけで電子顕微 鏡写真を撮ってみますと（写真 6,7 参照）, 非常に小さな 現像銀がたくさん集まって1つの集落を作っているのが 数多く見られます．これらの集落の 1 つ 1 つが臭化銀 1 個の大ささに匹敵することは, 数学的処理でわかってお ります. そのなかで, 核の中心部分が問題の標本の構造 の上を通っているかどらかを見ると, 通っているものも あるし, 通っていないものもある.も51度アルカリで 洗って，電子顕微鏡で同じところを撮ってみれば，ある いは流れたものが多いのではないかといらことがわかる かもしれないけれども，1度電子線を当てるとゼラチン がきれいにとれなくて，どうもきちんとしたデータにな らない。問題は，いま臭化銀の底面だけに最終的に核が 残る可能性があるかどうかといらことですが…...

小西 可能性もありらるといらことで，まだここで 結論はくだせないですね，いま，底面にできた核だけは 残るといらことを仮定して，それをもとにして幾何学的 に計算すれば, 先生のおっしゃるような分解能が出てく るといらことですね.ただ，そのへんをいかにして調べ るかということです.

中村 $\beta$ 線で粒子をワンヒットすれば, 必ず潜像が できるものだろらか. それは回復しない，つまり消えな いといらことを仮定してですね.

平田潜像はワンヒットで少なくとも1個ぐらいは できると考えていますが，たとえ潜像ができても，必ず その粒子が現像可能になり，現像銀になるといらわけで はありません．ワンヒットで潜像がでさるのも, 現像可 能になるのも， $\beta$ 線のエネルギー，八ロゲン化銀粒子の 感度によるわけです。レントゲンフィルムの乳剤粒子で すとワンヒットで充分現像可能になりますし, ェレクト ロン・センシティブの原子核乾板ですと, 最もエネルギ 一損失值の小さい Mev の $\beta$ 線でヒットされた場合, 10 個に 1 個は現像可能になります。しかし，ミクロオート ラジオグラフィ用の乳剂では, ワンヒットでは必ずしも 現像可能にはなりません。
一方， $\beta$ 線のエネルギーを低くしてゆきますと，エネ ルギー損失值が上がりますから，ワンヒットで現像可能 になる粒子の数が, 同じ感度でも増えてきます。 ${ }^{3} \mathrm{H}$ か らの $\beta$ 線の場合, 通常のミクロオートラジオグラフ用乳 剤で, ワンヒットで必ず現像可能になるかという質問に 対しては，数值を揭げてお答えはちょっとできませんが， 平均してそれに近いといえます。

進藤、ワンディスインテグレイションで, 必ず潜像 ができるといらふらに考えてよいわけですね，ただそ の潜像が現像によって銀粒子として現われるかどらかと いらことは別としてですね.

小西＼cjkstart実は，ワンディスインテグレイションでは 1 つのß線が出てきますが，それは必ずしもハロゲン化銀 結晶を貫くとは限っていません，たとえば，試料から乳 剤の塗ってある反対方向に飛びだせば，乳剂は通過しま せんがここいう確率は少なくとも $1 / 2$ はあります.

平田潜像にはふつう, 内部潜像と外部潜像とかい って, 粒子の表面にできる潜像と粒子の中にできる潜像 とがあります．とくに $\beta$ 線でヒットされた場合には，分 散してたくさんできてしまいます。それでも，低ェネル ギーの $\beta$ 線の場合は，ワンヒットで現像可能になる潜像 ができるといらことです.

進藤現像可能といらことで, 閾值のようなものが 考えられませんか. 現像可能といらことは, 光で表現す ると, 多量の光を 1 つの粒子に集中的に当てたといら効 果を示すものですが， $\beta$ 線が $1 つ$ 当たることによって， フリー・エレクトロンが非常にたくさん, 短い時間にで きるということですから，その点からいって，ほとんど 現像可能な潜像ができる.ただ，切片と接触していると ころだけに銀粒子が残るということを，臭化銀の結晶が 切片と接触しているといらことが，もし閏值のようなも のがあるとすれば，その閾值を下げるといら効果は考党 られないでしょらか.たとえば化学的な結合力のような 効果が.......

平田 感光にそれが寄与するといらことはらょっと 考えられないと思います，ただ，現像銀が標本にくっつ いたとすれば，洗い流したときにくくついて離れない だろらといらことは想像できます。これは目で見えるも のではないけれども……

水平 その場合に横から入った $\beta$ 線によっても大き い潜像ができる可能性は均等にあるわけですから，その 場合には残らないという説明が必要なのです.残ればハ ラッキが出てくる.

物理的な証明ができなくても，ある程度の解釈ができ 
なけ斻ば，われわれとしては実験データに信頼がもてな い、ただ，事実は小説よりも奇なりで，現在，私どもの 経験では, 解説にも書いたように, 非常に簃密な処理を すると，多少のバラッキはあるけれども，だいたいの場 合において，いわゆる標的構造の 100 300 ̊ の上に必 ずのっている．ただし，標的構造のターゲットに結合し ていないものは, 特そらく処理の途中で流れて出てこな いと考学れるけれぞも，それは別の問題になります。 ただ,この標的構造にのってきた銀粒子に比べるとはる かに小さい標点を，どういらふらに考光たらよいかとい ら問題です.そのようなことは信用できないと言下にい ってしまえば, 電子顕微鏡のオートラジオグラムは意味 がなくなってしまう。また，事実は事実として，裹づけ がないから事実だとはい壳ないにしても，事実のようだ から，それをるら少し考觉てみよらとしているわけです。

進藤電顕の場合には, 1 つグレイン+イズ以下 の問題にしぼってよいわけですね。

小西電子䫓微鏡の場合は，ほとんどグレインを 1 層にして、スペシメンが薄いから、ソースの部分とディ テクターの部分とか対応できる限界がせばまってもよい
と考党ているわけです.

中村 光䫓レベルの分解能では, 説明がついていた のですがそそれがより細かい構造を見るための電顕のレ ベルでは, 感光理論も一直線に下げてゆけばよいという わけにはゆかなくて，何か新しいものを考党㸚ば説明が つかなくなるといったことですね。

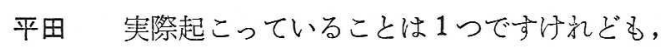
より細かいところまで論議されているということですね。 粒子 1 個については解説にあるように，充分に解釈でき ることですけれども。

水平私も一時期に電子顕微鏡によるオートラジオ グラフィも行き詰まったと内心考觉て和りましたが，そ の矢先, 微粒子現像の結果が非常によく出たことから, みなさんのご援助とご教示を得て，ますますこれから研 究を進める自信がついてきたような現状です。これから 先もまだわからない面がたくさんありますけれども，光 䫒やマクロのオートラジオグラフィともに，打互いに利 用しながら,こういら分野での細胞生理学の研究を大い に発展させてゆきたいと思っております。

どうもありがとうございました。

(おわり）

\section{受精卵の移植}

\section{大 梘 清 彥}

農林省畜産試験場

すぐれた遗伝形質をもつ家畜から多数の子を生産する 手段は, 家畜繁殖や遺伝分野に和引る1つの命題と考兄 られる. 雄の場合, 人工授精技術の確立によって, 一時 飞多量射出される優秀精子を短期間に広く普及できるこ とは，初期の目的にかなった方法である。これにひきか えて, 雌の場合, 生産される卵子が少なく,とくに牛の ような単胎動物については, 一生に 10 頭内外の子を産 出すれば満足とされている。このような問題を解決する 手段として, Heape (1890) が初めてウサギを用いて受 精卵移植に成功した技術が発展して, 実用への足がかり を作りあげる段階に達したわけである。この方法を，人 工授精に対して人工受胎あるいは人工妊娠とも呼んでい る.すなわち，一時に優良な形質をもつ受精卵を多量作 出し, 他の能力の低い雌畜の生殖器内にとれらの受精卵 を移植し，発育させることが目的である。したがって， これには, 過剩排卵の誘致, 受精卵の採取, 受精卵の保 存, 受精卵の移植など, それぞれ独立した技術の積み重

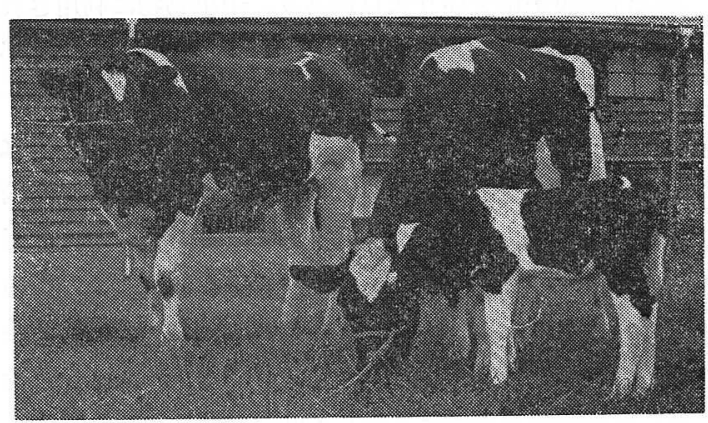

受精卵移植によって生まれた任牛と母牛

左から採眀母牛, 移植母牛, 仔牛 (親子篮別は血液型判定に上る)

〔杉江他：家息繁殖誌，11，124(1965) より]

ね片って成り立っているので，圭礼らの要点と今後の 問題について，家畜を中心として紹介する。

（1）過剩排卵の誘致：哺乳動物の卵栄内には原始 卵胞数が万を越えて存在する.しかし, 各種の条件から 一生に実際に利用される卵子は一部にすぎない，これら の消え去ってゆく卵子を有効に利用することが必要であ る.この方法として, gonadotrophin を利用して, 卵巣 内の卵胞成熟を進め，受精卵を多量作出することが行な われているが，家音の種類，個体によってかなりの差が 認められる。脳下垂体製剤を用いることが望昰しいが， 一般には娃馬血清性性腺刺激ホルモン (PMS) が用いら 